\title{
PENGARUH APLIKASI SENSOR SMARTPHONE PADA PEMBELAJARAN SIMPLE HARMONIC MOTION BERBASIS INKUIRI TERBIMBING TERHADAP PENINGKATAN KEMAMPUAN BERPIKIR KRITIS SISWA
}

\author{
Yoana Kristiyani, Feriansyah Sesunan, Ismu Wahyudi \\ Pendidikan Fisika, FKIP, Universitas Lampung \\ Email: yoanakristiyani09@gmail.com
}

Diterima: 11 Agustus 2020. Disetujui: 31 Agustus 2020.

\begin{abstract}
Abstrak
Penelitian ini bertujuan untuk mengetahui pengaruh penggunaan aplikasi phyphox pada materi getaran harmonis berbasis inkuiri terbimbing terhadap peningkatan kemampuan berpikir kritis siswa. Populasi pada penelitian ini seluruh siswa kelas X MIPA SMA N 1 Pringsewu. Sampel yang digunakan pada penelitian kelas X MIPA 4, berjumlah 30 siswa. Desain pada penelitian adalah One Group Pretest-Postest. Pembelajaran dilakukan dengan praktikum menggunakan alat berbantuan phyphox berbasis inkuiri terbimbing. Data kemampuan berpikir kritis diperoleh menggunakan tes tertulis. Analisis data hasil belajar siswa menggunakan Paired Sample TTest. Berdasarkan hasil penelitian diperoleh skor rata-rata kemampuan berpikir kritis siswa mengalami kenaikan sebesar $44 \%$ dengan rata-rata $N$ Gain sebesar 0,72 dalam kategori tinggi dan hasil uji paired simple T-test diperoleh nilai sig kurang dari 0,05. Disimpulkan bahwa terdapat perbedaan yang signifikan kemampuan berpikir kritis siswa sebelum dan sesudah menggunakan aplikasi phyphox.
\end{abstract}

Kata Kunci: gerak harmonis sederhana, inkuiri terbimbing, kemampuan berpikir kritis, phyphox.

\begin{abstract}
This study aims to determine the effect of the use of phyphox applications on guided inquiry-based harmonic vibration material to improve ability students' critical thinking. The population in this study were students of class $X$ MIPA SMA N 1 Pringsewu. The sample used in the study class X MIPA 4 with 30 students in total. The design of the study was One Group PretestPostest. Learning is done by practicum using a guided inquiry based phyphox application. Data in ability critical thinking were obtained using written tests. Data analysis of student learning outcomes using the Paired Sample T-Test. Based on the results of the study obtained an average score of ability students' critical thinking increased by $44 \%$ with an average $N$ Gain of 0.72 in the high category and the of paired simple T-test obtained a sig value of less than 0.05. It can be concluded that there are significant differences in ability students' critical thinking before and after using the phyphox application.
\end{abstract}

Keywords: simple harmonic motion, guided inquiry, critical thinking ability, phyphox. 
Kristiyani., Sesunan., Wahyudi - Pengaruh Aplikasi Sensor Smartphone ...

\section{PENDAHULUAN}

Kemenristekdikti

menyatakan bahwa perubahan dunia kini tengah memasuki era revolusi industri 4.0 atau revolusi industri dunia keempat di mana teknologi informasi telah menjadi basis dalam kehidupan manusia. Badan Standar Nasional Pendidikan (2010) memaparkan bahwa ciri model pendidikan abad 21, yaitu memanfaatkan teknologi pendidikan, pembelajaran berpusat kepada peserta didik, menggunakan metode pembelajaran kreatif yang berkaitan dengan kehidupan sehari- hari, serta menggunakan kurikulum yang mampu mengembangkan potensi diri siswa.

Fisika merupakan mata pelajaran yang berkaitan dengan mencari tahu tentang gejala - gejala alam secara sistematis yang menjadikan siswa berpikir kritis untuk membandingkan dua atau lebih informasi, dengan tujuan memperoleh pengetahuan melalui pengujian terhadap gejalagejala menyimpang dan kebenaran ilmiah (Damayanti, Ngazizah, \& Eko, 2012). Perkembangan teknologi dan bidang pendidikan juga tidak terlepas dari perkembangan bidang sains.

Menurut Hariawan, Kamaluddin, \& Wahyono (2013) mengungkapkan bahwa pembelajaran yang melibatkan pemahaman fenomena membuat siswa kesulitan, salah satunya pada materi fisika yaitu gerak harmonis sederhana yang dirasakan sulit oleh siswa. Handika

(2012) mengungkapkan bahwa faktor lain yang mempengaruhi kualitas pembelajaran diantaranya penggunaan metode dan media pembelajaran. Ketepatan menggunakan metode dan model pembelajaran akan menentukan tujuan dan peningkatan kemampuan akademik serta non akademik siswa.

Model pembelajaran yang diupayakan guru dalam ketercapaian belajar siswa adalah model pembelajaran yang memberikan keterlibatan siswa secara aktif, salah satunya yaitu model pembelajaran inkuiri terbimbing (Purwasih, 2015). Model inkuiri terbimbing dapat diterapkan dalam pembelajaran mengenai permasalahan pada konsep-konsep materi fisika. 
Kristiyani., Sesunan., Wahyudi - Pengaruh Aplikasi Sensor Smartphone ...

\begin{abstract}
Ertikanto (2016: 39)
mengungkapkan bahwa inkuiri

terbimbing merupakan pendekatan

pemecahan masalah dimana guru

membimbing siswa melakukan proses

ilmiah dan mengarahkan pada suatu

diskusi serta mengajak siswa untuk

aktif dan menemukan permasalahan

yang diberikan, tentunya menjadikan

siswa dapat menarik kesimpulan

secara mandiri dan mampu

menyelesaikan masalah. Ikuiri

terbimbing dianggap mampu dalam

meningkatkan proses pembelajaran.
\end{abstract}

Kegiatan belajar mengajar di kelas, memerlukan juga sarana dan prasarana pendukung seperti alat bantu atau media. Menurut Taufiq,

Dewi, \& Widyatmoko (2014) mengungkapkan bahwa penggunaan alat bantu berupa media dapat meningkatkan pembelajaran dengan lancar dan hasil yang maksimal.

Media yang digunakan dalam pembelajaran diantarannya media smartphone, sebagai suatu perantara yang berguna untuk membantu guru dalam mengajar dan memudahkan siswa menerima dan memahami pelajaran (Rahman, Hidayat \& Yanuttama, 2017).
Aplikasi phyphox merupakan program aplikasi yang sedang dikembangkan secara pesat dalam kegunaannya sebagai alat bantu pada saat percobaan materi fisika. Aplikasi ini mengintegrasikan berbagai sensor pada smartphone dan laptop sebagai dasar pengukuran eksperimental. Sensor pada aplikasi terbaca secara jelas dan data ditampilkan secara grafis serta dilengkapi banyak fitur inovatif, sehingga phyphox sangat baik untuk digunakan di sekolah.

Maretasari, ddk. menyatakan bahwa pembelajaran fisika semakin baik bila ditunjang dengan percobaan-percobaan oleh guru atau secara terbimbing di laboratorium. Penggunaan teknologi dalam proses pembelajaran juga berperan utama sebagai disiplin ilmu yang memfasilitasi pembelajaran agar terjadi efektif dan efisien dalam pembelajaran Pratama \& Haryanto (2017).

Penelitian ini untuk mengetahui pengaruh penggunaan media sensor smartphone pada pembelajaran gerak harmonis sederhana berbasis inkuiri terbimbing terhadap kemampuan berpikir kritis, maka penelitian ini 
Kristiyani., Sesunan., Wahyudi - Pengaruh Aplikasi Sensor Smartphone ...

difokuskan untuk menyelidiki variabel terikat dan variabel pengaruh penggunaan sensor moderator. Variabel bebas yaitu smartphone pada pembelajaran gerak aplikasi sensor smartphone phyphox, harmonis sederhana berbasis inkuiri variabel terikatnya kemampuan terbimbing terhadap kemampuan berpikir kritis dan variabel berpikir kritis siswa. moderatornya adalah inkuiri terbimbing.

\section{METODE}

Penelitian ini merupakan jenis penelitian eksperimen, dengan populasi adalah seluruh siswa kelas $\mathrm{X}$ MIPA di SMA Negeri 1 Pringsewu, semester genap tahun ajaran 2019/2020. Prosedur pengambilan sampel menggunakan purposive sampling dengan melihat hasil belajar siswa dan fasilitas belajar seperti laptop dan smartphone.

Sampel didapatkan kelas X MIPA 4 dengan jumlah 30 siswa sebagai kelas eksperimen. Desain penelitian one group pretest-posttest dapat dilihat pada tabel 1 .

Pada penelitian ini terdapat tiga variabel, yaitu variabel bebas,
Pengumpulan data menggunakan teknik tes, yaitu pretest dan posttest. Tes menggunakan lima item soal uraian kemampuan berpikir kritis, yang diberikan sebelum dan sesudah adanya perlakuan menggunakan aplikasi phyphox.

Teknik analisis data pada penelitian ini menggunakan uji normalitas untuk melihat apakah data yang diperoleh berdistribusi normal atau tidak dan uji $N$-Gain untuk melihat peningkatan kemampuan berpikir kritis. Analisis data dengan uji paired sample T-test, untuk mengetahui pengaruh aplikasi sensor smartphone phyphox terhadap kemampuan berpikir kritis.

Tabel 1. one group pretest-posttest

\begin{tabular}{ccc}
\hline Pretest & Perlakuan & Posttest \\
\hline$O_{1}$ & $X$ & $O_{2}$
\end{tabular}


Kristiyani., Sesunan., Wahyudi - Pengaruh Aplikasi Sensor Smartphone ...

\section{HASIL DAN PEMBAHASAN}

\section{Hasil}

Penelitian tentang pengaruh penggunaan aplikasi phyphox pada pembelajaran simple harmonic motion berbasis inkuiri terbimbing terhadap peningkatan kemampuan berpikir kritis, dilaksanakan pada tanggal 2-16 April 2020. Proses Pembelajaran berlangsung selama 3 kali pertemuan.

Hasil penelitian yang diperoleh berupa data kuantitatif, instrumen tes pada penelitian ini diujikan terlebih dahulu sebelum penelitian dilakukan.

Hasil uji validitas menunjukkan bahwa 4 soal uraian kemampuan berpikir kritis valid dengan hasil Pearson Correlation > 0,413. Selanjutnya dilakukan uji reliabilitas dengan hasil Cronbach's Alpha sebesar 0,775 yang menyatakan berarti instrument yang digunakan reliabel.

Hasil kemampuan berpikir kritis siswa diperoleh dengan cara memberikan soal pretest dan posttest. Data kuantitatif pretest diujikan pada awal pembelajaran, sedangkan hasil posttest pada akhir, dapat dilihat pada tabel 2 .

Tabel 2. Hasil Pretest dan Posttest Kemampuan Berpikir kritis

\begin{tabular}{lcc}
\hline Parameter & Pretest & Posttest \\
\hline Nilai terendah & 30 & 75 \\
Nilai tertinggi & 55 & 90 \\
Nilai Maksimum & 100 & 100 \\
Rata-rata nilai & 40 & 83 \\
\hline
\end{tabular}

Berdasarkan tabel 2 hasil rata-rata nilai pretest dan posttest kemampuan berpikir kritis siswa mengalami peningkatan. Namun, peningkatan kemampuan berpikir kritis tersebut belum terlihat secara signifikan, Adapun kemampuan berpikir kritis siswa yang diukur dalam soal pretest dan posttest dibagi menjadi lima indikator yaitu: bahwa butir-butir soal bersifat reliabel dan dapat digunakan karena berada diantara 0,60 sampai dengan 0,80 dalam kriteria reliabilitas tinggi. 
Kristiyani., Sesunan., Wahyudi - Pengaruh Aplikasi Sensor Smartphone ...

Namun, peningkatan kemampuan berpikir kritis tersebut belum terlihat secara signifikan, Adapun kemampuan berpikir kritis siswa yang diukur dalam soal pretest dan posttest dibagi menjadi lima indikator yaitu: penjelasan sederhana, keterampilan dasar, menyimpulkan, penjelasan lanjut, strategi dan taktik. Berikut rata-rata kemampuan berpikir kritis siswa pada tiap-tiap indikator yang ditampilkan pada tabel 3 .

Tabel 3. Rata-rata Kemampuan Berpikir Kritis pada setiap Indikator

\begin{tabular}{lccc}
\hline Indikator Berpikir kritis & \multicolumn{2}{c}{ Rata-rata } & Peningkatan \\
\cline { 2 - 3 } & Pretest & Posttest \\
\hline Penjelasan Sederhana & 48,83 & 82,67 & $69,3 \%$ \\
Keterampilan Dasar & 44,00 & 74,33 & $68,9 \%$ \\
Menyimpulkan & 41,17 & 69,00 & $67,6 \%$ \\
Penjelasan Lanjut & 37,50 & 63,00 & $68,0 \%$ \\
Strategi dan Taktik & 38,83 & 65,00 & $67,4 \%$ \\
\hline
\end{tabular}

Tabel 3 menunjukkan bahwa disebabkan oleh kemampuan siswa kemampuan berpikir kritis tiap-tiap dalam merumuskan dan menganalisis indikator mengalami peningkatan permasalahan yang disajikan dalam yang signifikan. Hasil tertinggi pada soal dengan sangat baik.

penelitian ini yaitu penjelasan Uji hipotesis menggunakan Paired sederhana sebesar 69,3\% dari sub- Sample T-test dengan uji normalitas indikator lainnya, dan hasil terendah sebagai uji prasyarat. Data penelitian yaitu pada indikator strategi dan yang digunakan dalam uji adalah $N$ taktik sebesar $67,4 \%$. Tingginya Gain kemampuan berpikir kritis dapat indikator penjelasan sederhana dilihat pada tabel 4.

Tabel 4. Rata-Rata N-Gain Kemampuan Berpikir Kritis

\begin{tabular}{ccccc}
\hline $\begin{array}{c}N \text {-Gain } \\
\text { Tertinggi }\end{array}$ & $\begin{array}{c}N \text {-Gain } \\
\text { Terendah }\end{array}$ & $\begin{array}{c}\text { Kenaikan Skor } \\
\text { Rata-rata }\end{array}$ & $\begin{array}{c}\text { Rata-rata } N \text { - } \\
\text { Gain }\end{array}$ & Kategori \\
\hline 0,86 & 0,55 & $44 \%$ & 0,72 & Tinggi \\
\hline
\end{tabular}


Kristiyani., Sesunan., Wahyudi - Pengaruh Aplikasi Sensor Smartphone ...

Berdasarkan tabel 4 menyatakan Rata- rata kenaikan mencapai 44\%, bahwa $N$-Gain kemampuan berpikir dalam kategori tinggi, selanjutnya kritis pada penelitian ini mengalami untuk uji normalitas data dapat dilihat peningkatan. $N$-Gain tertendah pada tabel 5 sebagai berikut :

sebesar 0,55 dan $N$-Gain tertinggi sebesar 0,86 .

Tabel 5. Hasil Uji Normalitas Kemampuan Berpikir Kritis

\begin{tabular}{cccc}
\hline Aspek & Sig & Berdistribusi Normal & $\begin{array}{c}\text { Tidak Berdistribusi } \\
\text { Normal }\end{array}$ \\
\hline Pretest & 0,256 & Normal & - \\
Posttest & 0,133 & Normal & - \\
\hline
\end{tabular}

Berdasarkan tabel 5 nilai menggunakan paired simple T-test, signifikasi pretest dan posttest hasil uji dapat dilihat pada tabel 6 .

kemampuan berpikir kritis lebih dari Berdasarkan tabel 6 diketahui 0,05, yang menyatakan bahwa data bahwa hasil nilai sig kurang dari 0,05 tersebut berdistribusi normal. yang artinya $H_{1}$ diterima.

Langkah selanjutnya yaitu dilakukan pengujian hipotesis

Tabel 6. Hasil Paired Sample T-Test Kemampuan Berpikir Kritis

\begin{tabular}{cccc}
\hline Pair & $\boldsymbol{T}$ & Df & Sig.(2-tailed) \\
\hline Pretest-Posttest & $-27,949$ & 29 & 0,00 \\
\hline
\end{tabular}

\section{Pembahasan}

Berdasarkan hasil uji paired simple T-test pada penelitian ini menunjukkan bahwa nilai sig kurang dari 0,05 yang artinya, terdapat perbedaan yang signifikan antara kemampuan berpikir kritis siswa sebelum dan sesudah pembelajaran menggunakan

aplikasi sensor smartphone.

Rata - rata $\mathrm{N}$-Gain kemampuan berpikir kritis siswa mengalami peningkatan sebesar $44 \%$ yang menunjukan dalam kategori tinggi. Purwasih (2015) menyatakan bahwa suatu rangkaian kegiatan 
Kristiyani., Sesunan., Wahyudi - Pengaruh Aplikasi Sensor Smartphone ...

pembelajaran yang menekankan pada proses berpikir secara kritis, analitis, mencari dan menemukan jawaban sendiri, dapat membantu siswa lebih memahami dan menjawaban dari suatu permasalahan yang diberikan.

Mengembangkan kemampuan berpikir kritis siswa, guru hendaknya memfasilitasi dan melakukan tindakan yang mendorong siswa merefleksikan kemampuan siswa, Noordyana (2016). Pembelajaran menggunakan aplikasi phyphox pada penelitian ini memiliki peranan selama proses pembelajaran berlangsung seperti: kegiatan praktikum dan kegiatan diskusi, yang dapat menuntut siswa untuk memecahkan masalah yang disajikan dengan cara sendiri sehingga mendorong peningkatan kemampuan berpikir kritis siswa. Diungkapkan juga oleh Sunaryo (2014) bahwa diskusi dan bahan ajar merupakan bagian penting dalam model pembelajaran berbasis masalah yang menjadi aspek pendukung dalam peningkatan kemampuan berpikir kritis siswa.

Saprudin et al., (2019) menyatakan bahwa aplikasi phyphox dapat merekam data dan hasil data tersebut dapat dibagi dalam format excel dan sangat membantu siswa. Adanya aplikasi phyphox sebagai aplikasi eksperimen fisika dianggap dapat menyelesaikan masalah dalam pembelajaran fisika.

Rahman, et al. (2017) mengungkapkan bahwa smartphone dapat digunakan sebagai alatbantu pembelajaran, untuk memudahkan siswa dalam proses pembelajaran, hal ini juga sangat membantu guru dalam mengajar. Smartphone memiliki peranan dalam peningkatan minat belajar siswa dalam mempelajari lebih lanjut tentang materi fisika. Diungkap juga oleh Maretasari, ddk. (2012) bahwa pembelajaran fisika semakin baik bila ditunjang dengan percobaan-percobaan oleh guru atau secara terbimbing di laboratorium.

Proses pembelajaran untuk mencapai hasil yang optimal dibutuhkan siswa secara aktif dalam pembelajaran. Inkuiri terbimbing merupakan model pembelajaran yang menuntut siswa untuk berperan aktif dalam memecahkan permasalahan Ahmatika (2017). 
Kristiyani., Sesunan., Wahyudi - Pengaruh Aplikasi Sensor Smartphone ...

Diungkapkan juga oleh Rizal hubungan permasalahan yang (2014) bahwa pembelajaran akan disajikan dalam soal. Keempat sublebih bermakna jika siswa diberi indikator menyimpulkan sebesar kesempatan untuk tahu dan terlibat secara aktif dalam menemukan konsep dari fenomena yang ada dari lingkungan dengan bimbingan guru, salah satu model pembelajaran inkuiri terbimbing.

Pada penelitian ini peningkatan kemampuan berpikir kritis mengalami kenaikan yang cukup tinggi pada indikator penjelasan sederhana sebesar 69,3\%, tingginya capaian indikator tersebut disebabkan oleh kemampuan siswa dalam merumuskan dan mengalasisis soal yang disajikan sudah sangat baik setelah mengamati percobaan menggunakan aplikasi phyphox, siswa lebih mudah memahami materi dan konsep. Sub-indikator kedua yaitu keterampilan dasar sebesar 68,9\%, siswa dapat mengidentifikasi penjelasan dengan cermat dalam memberikan penjelasan pada masalah yang disajikan.

Ketiga yaitu sub-indikator penjelasan lanjut sebesar 68, $0 \%$, siswa dapat memberikan penjelasan secara detail dan menentukan pola $67,6 \%$ siswa mudah memahami dan menarik kesimpulan dari permasalahan yang disajikan sesuai dengan fakta dan teori. Sub-indikator terakhir yaitu strategi dan taktik sebesar 67,4 \% siswa masih cenderung kurang menunjukan dan menentukan pemecahan masalah dengan tepat pada soal yang disajikan.

Nurfadilah et al., (2019) menyatakan bahwa kegiatan praktikum merupakan bagian penting dalam fisika yang berorientasi pada keterampilan proses sains. Inkuiri terbimbing memberikan kesempatan kepada siswa untuk belajar aktif dalam berinteraksi dan kegiatan diskusi, sehingga siswa akan lebih mudah memahami materi dan konsep.

Peningkatan penguasaan konsep siswa juga adanya kegiatan praktikum dengan aplikasi phyphox, siswa menggunakan dan memanfaatkan teknologi dengan sangat baik dan aktif. Sesuai dengan hasil pendapat Sesen \& Tarhan (2013) bahwa pembelajaran berbasis inkuiri dengan 
Kristiyani., Sesunan., Wahyudi - Pengaruh Aplikasi Sensor Smartphone ...

aktivitas laboratorium merupakan suatu kombinasi yang efektif dalam kegiatan pembelajaran.

\section{KESIMPULAN DAN SARAN}

\section{Kesimpulan}

Pembelajaran dengan

menggunakan aplikasi phyphox memiliki pengaruh yang signifikan terhadap peningkatan kemampuan berpikir kritis siswa, diperoleh ratarata $N$-Gain 0,72 kategori tinggi dengan hasil analisis paired simple $T$ test menunjukan nilai sig lebih kecil dari 0,05 sehingga terdapat perbedaan rata-rata kemampuan berpikir kritis sebelum dan sesudah pembelajaran menggunakan sensor smartphone phyphox.

\section{Saran}

Berdasarkan hasil penelitian yang telah dilakukan, disarankan bahwa:

Percobaan dengan aplikasi phyphox memiliki akurasi yang tinggi dan perlu diperhatikan alat praktikum yang digunakan dalam keadaan baik, sehingga tidak terjadi kesalahan sensor yang terbaca pada aplikasi phyphox Aplikasi phyphox dapat digunakan untuk pembelajaran fisika karena sensor hasil data percobaan terbaca pada layar laptop atau smartphone dan data ditampilkan secara grafis serta dilengkapi banyak fitur inovatif, sehingga phyphox sangat baik untuk digunakan di sekolah.

\section{DAFTAR PUSTAKA}

Ahmatika, D. 2017. Peningkatan Kemampuan Berpikir Kritis Siswa Dengan Pendekatan Inquiry/ Discovery. Jurnal Euclid, Online. 3 (1), 377-525.

Damayanti, D. S., Ngazizah, N. K., \& Eko, S. 2012. Pengembangan Lembar Kerja Siswa (Lks) Dengan Pendekatan Inkuiri Terbimbing Untuk Mengoptimalkan Kemampuan Berpikir Kritis Peserta Didik Pada Materi Listrik Dinamis Sma Negeri 3 Purworejo Kelas X Tahun Pelajaran 2012/2013. Jurnal Radiasi. Online. 3 (1),

69-77.

Ertikanto, C. 2016. Teori Belajar Dan Pembelajaran. Yogyakarta: Media Akademi. 192

Handika, J. 2012. Efektivitas Media Pembelajaran IM3 Ditinjau dari Motivasi Belajar. Jurnal Pendidikan IPA Indonesia. Online. 1 (2), 109-114.

Hariawan, Kamaluddin, \& Wahyono, U. 2013. Pengaruh Model Pembelajaran Creative Problem Solving Terhadap Kemampuan Memecahkan Masalah Fisika 
Kristiyani., Sesunan., Wahyudi - Pengaruh Aplikasi Sensor Smartphone ...

Pada Siswa Kelas Xi Sma Negeri

4 Palu. Jurnal Pendidikan Fisika

Tadulako (JPFT). Online. 1 (2), 48-55.

Maretasari, E., Subali, B., \& Hartono. 2012. Penerapan Model Pembelajaran Inkuiri Terbimbing Berbasis Laboratorium Untuk Meningkatkan hasil Belajar dan Sikap Ilmiah Siswa. Unnes Physics Education Journal. Online. 1 (2), 27-31.

Noordyana, M. A. 2018. Meningkatkan Kemampuan Berpikir Kritis Matematis siswa Melalui Pendekatan Metacognitive Instruction. Jurnal Pendidikan Matematika STKIP Garut. Online. 5 (2), 177-180.

Nurfadilah, Ishafit, Herawati, R., \& Nurulia, E. 2019. Pengembangan Panduan Eksperimen Fisika Menggunakan Smarthphone dengan Aplikasi Phyphox Pada Materi Tumbukan. Jurnal Penelitian Pembelajaran Fisika. Online. 10 (2), 101-107.

Pratama, U. N., \& Haryanto. 2017. Pengembangan Game Edukasi Berbasis Android Tentang Domain Teknologi Pendidikan. Jurnal Inovasi Teknologi Pendidikan. Online. 4 (2), 167184.

Putra, P. D. A., \& Sudarti. 2009. Real Life Video Evaluation Dengan Sistem E-Learning Untuk Meningkatkan Keterampilan Berpikir Kritis Mahasiswa. Jurnal Kependidikan. Online. 45 (1), 76-89.
Purwasih, R. 2015. Peningkatan Kemampuan Pemahaman Matematis dan Self Confidence Siswa Mts di Kota Cimahi Melalui Model Pembelajaran Inkuiri Terbimbing. Jurnal Ilmiah STKIP Siliwangi Bandung. Online. 9 (1), 16-25.

Rahman, A. Z., Hidayat, T. N., \& Yanuttama, I. 2017. Media Pembelajaran IPA Kelas 3 Sekolah Dasar Menggunakan Teknologi Augmented Reality Berbasis Android. Jurnal STMIK AMIKOM. Online. 1 (2), 44-48.

Rizal, M. 2014. Pengaruh Pembelajaran Inkuiri Terbimbing dengan Multi Representasi terhadap Keterampilan Proses Sains dan Penguasaan Konsep IPA siswa SMP. Jurnal Pendidikan Sains. Online. 2 (3), 159-165.

Sanjaya, W. 2012. Strategi Pembelajaran Berorientasi Standar Proses Pendidikan. Jakarta: Kencana Prenada Media Group. 308.

Saprudin, Liliasari, Prihatmanto, A. S., \& Setiawan, A. 2019. The Potential of Gamification in Developing Pre-Service Physics Teachers, Critical and Creative Thinking Skills. Jurnal Fisika dan Pendidikan Fisika. Online. 2 (1), 7-14.

Sesen, B. A., \& Tarhan L. 2013. "Inquiry Based Laboratory Activities in Electrochemistry: High School Students' Achievement and Attitudes". Jurnal Research Science 
Kristiyani., Sesunan., Wahyudi - Pengaruh Aplikasi Sensor Smartphone ...

Education. Online. 1 (43), 413435.

Taufiq, M., Dewi, N. R., \& Widiyatmoko, Pengembangan

Pembelajaran
A. 2014. Media IPA Terpadu
Berkarakter Peduli Lingkungan Tema "Konservasi" Berpendekatan Science Edutainment. Journal Unnes. Online. 3 (2), 140-145. 